\title{
MENGEMBANGKAN SELF-EFFICACY MATEMATIKA MELALUI PEMBELAJARAN PENDEKATAN MATEMATIKA REALISTIK PADA SISWA KELAS VII D SMP NEGERI 27 BANJARMASIN TAHUN PELAJARAN 2016-2017
}

\author{
Pahrul Arifin, Benny Nawa Trisna, Muh. Fajaruddin Atsnan \\ Pendidikan Matematika STKIP PGRI Banjarmasin \\ Pahru109@gmail.com, benny@stkipbjm.ac.id, atsnan@stikip.ac.id
}

\begin{abstract}
Abstrak: Penelitian ini bertujuan untuk: (1) Mengetahui self-efficacy siswa terhadap matematika sebelum dan sesudah pembelajaran melalui Pendekatan Matematika Realistik. (2) Mengetahui perkembangan self-efficacy siswa terhadap matematika sebelum dan sesudah pembelajaran dengan Pendekatan Matematika Realistik. Jenis penelitian ekperimen dengan desain penelitian one group pretest and posttes design, dengan populasi siswa kelas VII SMP Negeri 27 Banjarmasin tahun peajaran 2016/2017. sampel penelitian dipilih dengan teknik purpossive sampling, sebanyak 30 orang siswa di kelas VII D. Teknis analisis data yang digunakan teknik analisis deskriptif dan data analisis kuantitatif. Hasil penelitian menunjukkan self-efficacy siswa terhadap matematika sebelum perlakuan dengan persentase kategori rendah $40 \%$, kategori sedang 47\%, dan $13 \%$ termasuk kategori tinggi. Sedangkan self-efficacy siswa terhadap matematika setelah pembelajaran melalui PMR, diperoleh persentase selfefficacy siswa terhadap matematika 3\% yang termasuk kategori rendah, 73\% untuk kategori sedang, dan 23\% untuk kategori tinggi. Melalui uji Wilcoxon pada taraf signifikan 5\% memperlihatkan nilai Sig. Sebesar 0,000 lebih kecil dari $\alpha=0,005$. Kesimpulan dari penelitian ini adalah perkembangan selfefficacy siswa terhadap matematika melalui Pendekatan Matematika Realistik lebih baik dibandingkan pembelajaran sebelumnya. Sebagai implikasi dari hasil penelitian ini sebagai alternatif untuk mengembangkan self-efficacy siswa terhadap matematika hendaknya guru menggunakan model pembelajaran dengan pendekatan matematika realistik.
\end{abstract}

Kata kunci : self-efficacy, Pendekatan Matematika Realistik (PMR)

Matematika merupakan telaah tentang pola dan hubungan saatu jalan atau pola fikir, suatu seni, suatu bahasa, dan suatu alat. Hakikat matematika bersifat abstrak, sehingga pelajaran matematika menjadi menakutkan dan sulit bagi sebagian besar siswa. Guna mengubah presepsi tersebut mengembangkan minat dan rasa senang siswa terhadap pelajaran matematika, terutama dalam menanamkan rasa percaya diri yang kuat ketika mempelajari atau menyelesaikan masalah matematika. Tujuannya agar pembelajaran matematika yang bermakna bagi siswa sehingga memberikan bekal kompetensi yang memadai, baik untuk studi lanjut maupun untuk memasuki dunia kerja (Hendriana, Sumarno 2014:9).

Sedangkan self-efficacy matematika sendiri adalah penilaian terhadap diri sendiri terhadap kemampuan yang dimiiki dalam menyelesaikan masalah matematika. Selfefficacy matematika memiliki kontribusi positif serta peranan yang sangat penting terhadap prestasi belajar matematika yang dapat dicapai oleh siswa. Self-efficacy matematika yang tinggi akan mendorong 
pencapaian prestasi belajar matematika siswa yang lebih baik.

Bandura (1997) mengemukakan bahwa self-efficacy merupakan suatu faktor penentu pilihan utama untuk pengembangan individu, ketekunan dalam menggunakan berbagai kesulitan, dan pemikiran memola dan reaksireaksi emosional yang dialami. Self-efficacy dapat dikembangkan dari diri siswa dalam pembelajaran matematika, melalui empat sumber, yaitu (1) pengalaman kinerja; (2) pengalaman orang lain; (3) aspek dukungan langsung/sosial; dan (4) aspek psikologi dan afektif.

Menurut Bandura (Ghufron dan Risnawita, 2010: 80), self-efficacy pada diri seseorang akan berbeda antara satu orang dengan yang lainnya diantara:

\section{1) Tingkat Kesulitan (Magnitude/Level)}

Tingkat kesulitan (magnitude/level) berkaitan dengan derajat kesulitan tugas ketika seseorang merasa mampu untuk melakukannya. Dimensi ini memiliki implikasi terhadap pemilihan tingkah laku yang akan dicoba atau dihindari. Seseorang akan mencoba tingkah laku yang dirasa mampu dilakukannya dan menghindari tingkah laku yang dirasa tidak mampu dilakukannya. Dimesi magnitude/level berhubungan dengan tingkat kesulitan yang diyakini dapat diselesaikan oleh sesorang.

2) Tingkat Kekuatan (Strength)

Tingkat kekuatan (Strength) berkaitan dengan tingkat kekuatan dari keyakinan atau pengharapan seseorang mengenai kemampuannya. Pengharapan seseorang yang lemah mudah dirubah oleh pengalamanpengalaman yang tidak menyenangkan. Sebaliknya, pengharapan yang meyakinkan akan mendorong seseorang tetap bertahan dalam usahanya. Dimensi ini berkaitan dengan dimensi level, yaitu semakin tinggi taraf kesulitan maka semakin lemah keyakinan yang dirasakan untuk menyelesaikan kesulitan tersebut.

\section{3) Tingkat Generalisasi (Generality)}

Tingkat generalisasi (Generality) berkaitan dengan luas bidang tingkah laku yang dirasakan seseorang yakin akan kemampuannya. Seseorang dapat merasa yakin terhadap kemampuan dirinya. Apakah terbatas pada suatu aktivitas dan situasi tertentu atau pada serangkaian aktivitas dan situasi yang bervariasi.

Menurut Stipek dalam La Moma (2014) mengemukakan bahwa strategi pembelajaran untuk mengembangkan self-efficacy siswa antara lain:

1) Ajarkan strategi spesifik. Ajari siswa strategi tertentu, seperti menyusun garis besar dan ringkasan, yang dapat meningkatkan kemampuan mereka untuk fokus pada tugas mereka.

2) Bimbing siswa dalam menentukan tujuan. Bantu mereka membuat tujuan jangka pendek setelah mereka membuat tujuan jangka panjang. Tujuan jangka pendek terutama membantu siswa untuk menilai kemajuan mereka.

3) Pertimbangkan mastery. Beri imbalan pada kinerja siswa, imbalan yang mengisyaratkan penghargaan penguasaan atas materi, bukan imbalan hanya kerena melakukan tugas.

4) Sediakan dukungan bagi siswa, dukungan positif yang berasal dari guru, orang tua dan teman sebaya. 
5) Pastikan agar siswa tidak terlalu semangat atau terlalu cemas, jika siswa terlalu takut dan meragukan prestasi mereka maka rasa percaya diri mereka bisa hilang.

6) Beri contoh positif dari orang dewasa dan teman sebaya. Karakteristik tertentu dari model atau teladan ini bisa membantu siswa mengembangkan selfefficacy mereka.g

Menurut Del Siegle dan D. Betsy Mc Coach (2007) dalam Journal of Advance Academics menyatakan instruksi-instruksi yang dapat digunakan untuk meningkatkan self-efficacy siswa, diantaranya:

1) Mengulang pelajaran yang lalu, menyampaikan tujuan pembelajaran, memperhatikan jalannya pembelajaran agar tercapai tujuan pembelajaran, dan mengulang tujuan pembelajaran di akhir pelajaran.

2) Menyuruh siswa untuk mencatat hal-hal baru apa saja yang telah mereka dapatkan hari itu atau yang istimewa.

3) Mendorong siswa yang kurang mampu dalam menggunakan kegagalan mereka untuk berusaha lebih keras.

4) Menggambarkan perhatian siswa terhadap pertumbuhan mereka dan memuji mereka atas kemampuan khusus mereka.

5) Menggunakan contoh siswa sebagai orang yang sudah mampu menguasai materi untuk menunjukkan bahwa mereka telah menguasainya dan siswa lain pun mampu menguasainya seperti mereka.
Kenyataannya di lapangan berdasarkan hasil wawancara yang telah dilakukan peneliti dengan ibu Hj Halimatus Sa' diah S.Pd., selaku guru pengampu mata pelajaran matematika dikelas VII SMPN Negeri 27 Banjarmasin tahun Pelajaran 2016/2017. Selama proses pembelajaran matematika berlangsung, masih banyak siswa yang: a) ragu-ragu saat mengemukakan pendapat, b) kurangnya minat terhadap matematika sehingga mereka cenderung cepat menyerah saat mengerjakan tugas, c) lebih meyakini jawaban yang dikerjakan oleh temannya, dan d) hasil belajarnya belum sesuai harapan atau rendah.

Melihat permasalahan yang ada, maka salah satu strategi pembelajaran inovatif yang dapat diterapkan adalah Pendekatan Matematika Realistik (PMR). Karena dalam PMR diupayakan materi matematika menjadi perluasan hasil penemuan siswa sendiri (dengan bantuan guru), dan mengubah kebiasaan dari pembelajaran yang menuntut siswa untuk mendengar, mencatat, menghafal rumus-rumus, dan mengerjakan soal-soal rutin menjadi pembelajaran yang mengajak siswa bekerja, menemukan matematika dengan cara mereka sendiri dari masalah kontekstual yang realistik serta merefleksi proses, mendiskusikan proses dan hasil temuan kelompok siswa, mengaitkan temuannya dengan pengetahuan sebelumnya dan menyajikan kesimpulannya di depan kelas.

Maka peneiliti bermaksud untuk meneliti sejauh mana Pendekatan Matematika Realistik mampu mengembangkan selfefficacy siswa terhadap Matematika. Dengan rumusan masalah (1) Bagaimana self-efficacy siswa terhadap matematika sebelum dan sesudah pembelajaran melalui Pendekatan Matematika Realistik. (2) Apakah perkembangan self-efficacy siswa terhadap 
matematika sesudah diterapkan Pendekatan Matematika Realistik lebih baik dibandingkan sebelum diterapkan Pendekatan Matematika Realistik.

\section{Metode Penelitian}

Jenis Penelitian ini merupakan jenis penelitian ekperimen dengan desain penelitian yang digunakan dalam penelitian Pre Experimental Design. Penelitian ini hanya menggunakan satu kelas saja tanpa adanya kelas kontrol "One Group Pretest - Posttest Design”.

Tabel 1 Desain Penelitian One Group Pretest Posttest Design

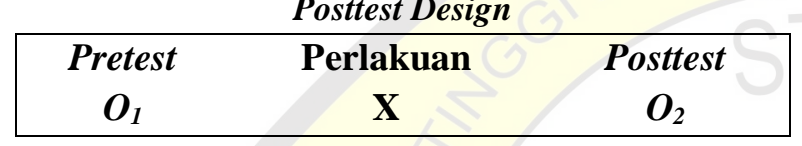

Sumber : (Eka dan Ridwan, 2015:122).

Keterangan:

$\mathbf{X}=$ Perlakuan (treatment) terhadap sampel.

$\mathbf{O}_{1}=$ Tingkat self-efficacy siswa Sebelum perlakuan.

$\mathbf{O}_{2}=$ Tingkat self-efficacy siswa Sesudah perlakuan.

Populasi penelitian ini adalah seluruh siswa kelas VII SMP Negeri 27 Banjarmasin semester genap tahun ajaran 2016/2017. Sedangkan untuk sampel penelitian adalah siswa kelas VII D dengan jumlah siswa sebanyak 30 orang, yang dipilih dengan teknik Purpossive Sampling, dengan pertimbangan berdasarkan hasil wawancara dengan guru pengampu mata pelajaran matematika $\mathrm{Ibu} \mathrm{Hj}$ Halimatus sa'diah S.Pd., yang mengatakan bahwa siswa di kelas VII D diperkirakan memiliki self-efficacy yang rendah jika dibandingkan dengan kelas lainnya. Hal tersebut karena dikelas VII D siswa masih banyak yang: a) ragu-ragu mengemukakan pendapat, b) cenderung cepat menyerah saat mengerjakan tugas, c) lebih meyakini jawaban yang dikerjakan oleh temannya, dan d) hasil belajarnya belum sesuai harapan atau rendah.

Data dalam penelitian ini ada data kuantitatif dan data kualitatif. Data kuantitatif diperoleh melalui analisis terhadap jawaban siswa pada angket skala self-efficacy matematika siswa. Data kualitatif diperoleh melalui hasil jurnal siswa selama pelaksanaan pembelajaran, yang kemudian dianalisis secara deskriptif untuk mendukung kelengkapan data kuantitatif dalam menjawab pertanyaan penelitian. Untuk keperluan uji perbedaan digunakan Uji peringkat bertanda Wilcoxon (wilcoxon signed ranks test) merupakan penyempurnaan dari uji tanda (signed test). Digunakan untuk analisis statistik dua sampel dependen jika data yang akan dianalisis berskala ordinal atau nominal (Eka dan Ridwan, 2015:274).

\section{Hasil dan Pembahasan}

\section{Hasil}

1) Data hasil Pretest Self-Efficacy Siswa

Data hasil pretest merupakan data yang diperoleh melalui angket self-efficacy sebelum diberi perlakuan. Pengambilan data ini bertujuan untuk mengetahui self-efficacy terhadap matematika sebelum dilakukan pembelajaran. pembelajaran yang dimaksud yaitu melalui Pendekatan Matematika Realistik.

Tabel 1 Kategori self-efficacy siswa sebelum perlakuan

\begin{tabular}{|c|c|c|c|}
\hline Interval & Kategori & $\mathrm{F}$ & Persentase \\
\hline $\mathrm{X} \geq 120$ & Tinggi & 4 & $13 \%$ \\
\hline $80 \leq \mathrm{X}<120$ & Sedang & 14 & $47 \%$ \\
\hline $\mathrm{X}<100$ & Rendah & 12 & $40 \%$ \\
\hline \multicolumn{2}{|r|}{ Jumlah } & 30 & $100 \%$ \\
\hline
\end{tabular}


Dari tabel 1, dilihat bahwa 4 siswa dengan persentase $13 \%$ yang termasuk kategori tinggi, 14 siswa termasuk kategori sedang $47 \%$, dan jumlah siswa yang kategori self-efficacy rendah berjumlah 4 siswa dengan persentase $13 \%$.

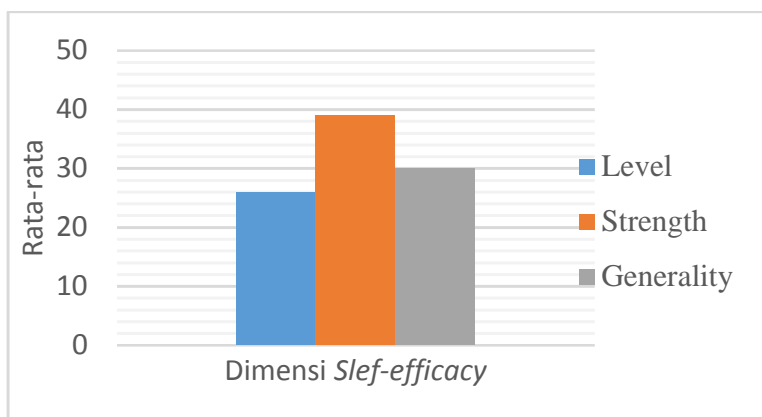

Gambar1. Rata-rata Self-efficacy siswa berdasarkan dimensi

2) Data Hasil Posttest Self-efficacy Siswa

Selanjutnya akan di analisis data hasil angket self-efficacy siswa terhadap matematika sesudah diberi perlakuan.

Tabel 2. Kategori self-efficacy siswa sesudah perlakuan

\begin{tabular}{|c|c|c|c|}
\hline Interval & Kategori & $\mathrm{F}$ & Persentase \\
\hline $\mathrm{X} \geq 120$ & Tinggi & 7 & $23 \%$ \\
\hline $80 \leq \mathrm{X}<120$ & Sedang & 22 & $74 \%$ \\
\hline $\mathrm{X}<100$ & Rendah & 1 & $3 \%$ \\
\hline Jumlah & & 30 & $100 \%$ \\
\hline
\end{tabular}

Setelah diberi perlakuan self-efficacy siswa terhadap matematika menjadi 1 siswa dengan persentase $3 \%$ yang termasuk di dalam kategori rendah, 22 siswa termasuk kategori sedang dengan persentase $74 \%$, dan jumlah siswa yang kategori self-efficacy tinggi berjumlah 7 orang dengan persentase $23 \%$.

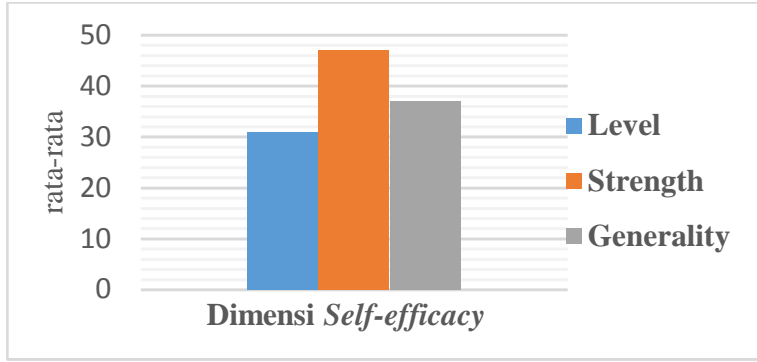

Gambar 2. Rata-rata skor berdasarkan dimensi selfefficacy

3) Self-efficacy siswa terhadap matematika sebelum dan sudah perlakuan

Berikut akan disjikan kategori selfefficacy siswa terhadap matematika berdasarkan hasil angket self-efficacy siswa yang diisi sebelum dan sesudah perlakuan.

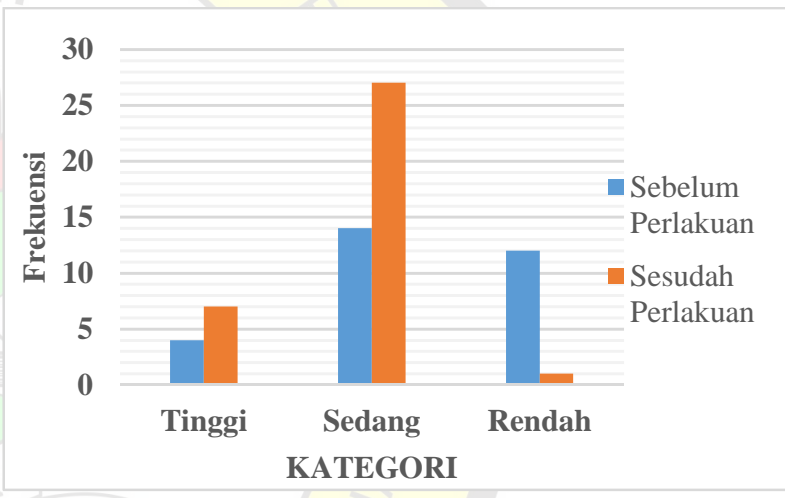

Gambar 3. Kategori self-efficacy siswa

Pada gambar 3 terlihat bahwa selfefficacy siswa terhadap matematika, dimana siswa dengan kategori self-efficacy tinggi sebelum perlakuan terdapat 4 siswa dan setelah perlakuan menjadi 7 siswa, untuk siswa dengan kategori self-efficacy sedang 14 siswa setelah perlakuan menjadi 27 siswa dengan kategori sedang, untuk siswa dengan kategori self-efficacy rendah sebelum perlakuan terdapat 12 siswa namun setelah perlakuan hanya terdapat 1 orang siswa yang memiliki self-efficacy terhadap matematika yang rendah. Jika dilihat berdasarkan dimensi selfefficacy siswa terhadap matematika liahat diagram dibawah ini: 


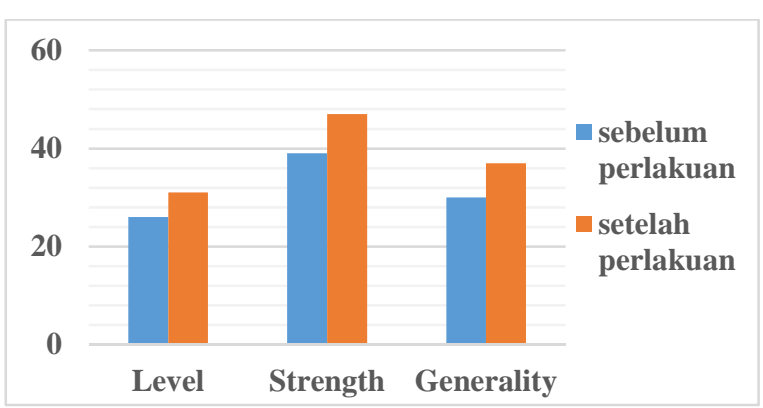

Gambar 4. Self-efficacy siswa berdasarkan dimensi Self-efficacy.

Hasil penelitian menunjukkan bahwa terdapat perbedaan antara pencapaian selfefficacy siswa terhadap matematika sebelum dan sesudah perlakuan. Hal ini didasarkan pada perolehan persentase skor angket selfefficacy siswa terhadap matematika sebelum pembelajaran melalui Pendekatan Matematika Realistik dengan persentase kategori rendah $40 \%$, kategori sedang $47 \%$, dan yang termasuk kategori tinggi $13 \%$. Sedangkan self-efficacy siswa terhadap matematika setelah penerapan pembelajaran melalui Pendekatan Matematika Realistik, diperoleh data tentang persentase self-efficacy siswa terhadap matematika menjadi $3 \%$ yang termasuk kategori rendah, $74 \%$ untuk siswa yang termasuk kategori sedang, dan 23\% untuk kategori tinggi.

Untuk mengetahui apakah perkembangan self-efficacy siswa terhadap matematika sesudah diterapkan Pendekatan Matematika Realistik lebih baik dibandingkan sebelum diterapkan Pendekatan Matematika Realistik. Maka data tersebut akan diuji menggunakan uji Wilcoxon yang digunakan dalam penelitian ini yaitu uji Wilcoxon dua sampel yang dependen (tetap) dengan bantuan apkikasi SPSS 16.0 dengan taraf kepercayaan $5 \%$ dengan hipotesis:

$H_{0}: \mu_{1} \leq \mu_{2} \quad$ :Perkembangan self-efficacy siswa terhadap matematika sesudah diterapkan Pendekatan Matematika Realistik tidak lebih baik dibandingkan sebelum diterapkan Pendekatan Matematika Realistik.

$H_{u}: \quad \mu_{1}>\mu_{2}$ :Perkembangan self-efficacy siswa terhadap matematika sesudah diterapkan Pendekatan Matematika Realistik lebih baik dibandingkan sebelum diterapkan Pendekatan Matematika Realistik.

Tabel 3. Hasil Test Statistics $^{\text {b,c }}$ SPSS 16.0

\begin{tabular}{|c|c|c|c|}
\hline & & & $\begin{array}{c}\text { postest - } \\
\text { pretes }\end{array}$ \\
\hline \multicolumn{3}{|c|}{$\mathrm{Z}$} & $-4.721^{a}$ \\
\hline \multicolumn{3}{|c|}{ Asymp. Sig. (2-tailed) } & .000 \\
\hline \multirow{3}{*}{$\begin{array}{l}\text { Monte } \\
\text { Carlo } \\
\text { Sig. (2- } \\
\text { tailed) }\end{array}$} & \multicolumn{2}{|c|}{ Sig. } & .000 \\
\hline & \multirow{2}{*}{$\begin{array}{c}95 \% \\
\text { Confidence } \\
\text { Interval }\end{array}$} & $\begin{array}{l}\text { Lower } \\
\text { Bound }\end{array}$ & .000 \\
\hline & & $\begin{array}{l}\text { Upper } \\
\text { Bound }\end{array}$ & .000 \\
\hline \multirow{3}{*}{$\begin{array}{l}\text { Monte } \\
\text { Carlo } \\
\text { Sig. (1- } \\
\text { tailed) }\end{array}$} & \multirow{2}{*}{$\begin{array}{c}95 \% \\
\text { Confidence } \\
\text { Interval }\end{array}$} & $\begin{array}{l}\text { Lower } \\
\text { Bound }\end{array}$ & .000 \\
\hline & & $\begin{array}{l}\text { Upper } \\
\text { Bound }\end{array}$ & .000 \\
\hline & \multicolumn{2}{|c|}{ Sig. } & .000 \\
\hline \multicolumn{4}{|c|}{ a. Based on negative ranks. } \\
\hline \multicolumn{4}{|c|}{ b. Wilcoxon Signed Ranks Test } \\
\hline \multicolumn{4}{|c|}{$\begin{array}{l}\text { c. Based on } 10000 \text { sampled tables with starting seed } \\
2000000 \text {. }\end{array}$} \\
\hline
\end{tabular}

Output yang dilakukan melalui uji wilcoxon untuk dua sampel yang dependen diperoleh hasil uji SPSS $Z_{\text {hitung }}=-4.721$ berdasarkan rank negatif. Karena pengujian yang dilakukan uji satu pihak (uji pihak kanan) maka $\mathrm{P}_{\text {value }}$ yang digunakan adalah monte carlo sig (1-tailed) yaitu $\mathrm{P}_{\text {value }}=0.000$ sedangkan $\alpha=0.05$. karena $\mathrm{P}_{\mathrm{v}} \quad<\alpha$ maka Ho ditolak dan Ha diterima, dengan taraf 
kepercayaan 95\%. Maka dapat disimpulkan Perkembangan self-efficacy siswa terhadap matematika sesudah diterapkan Pendekatan Matematika Realistik lebih baik dibandingkan sebelum diterapkan Pendekatan Matematika Realistik.

\section{Pembahasan}

1) Tingkat kesulitan (magnitude/level)

Berkaitan dengan tingkat kesulitan tugas ketika seseorang merasa mampu untuk melakukannya. Dengan rata-rata skor skor sebelum perlakuan yaitu 26 merupakan skor terendah dibanding dimensi lainnya. Hal itu bearti dikelas VII D SMP Negeri 27 Banjarmasin ketika mereka menghadapi masalah maka setiap orang akan berbeda memandang masalah tersebut, ada yang merasa masalah tersebut sulit bagi dirinya dan ada yang merasa masalah tersebut mudah atau sedang bagi dirinya. Hal ini mengakibatkan ketika mereka dihadapkan pada soal atau masalah yang lebih sulit, mereka hanya akan mencoba yang menurut mereka mampu dilakukannya dan menghindari tingkah laku yang dirasa tidak mampu dilakukannya. Dengan demikian, siswa dengan self-efficacy rendah terhadap tugas tertentu lebih berpikir tentang kekurangan pribadi mereka daripada berpikir tentang menyelesaikan tugas, sehingga akan menghambat kinerja keberhasilan menyelesaikan tugas.

\section{2) Tingkat kekuatan (strength)}

Dimensi ini berkaitan dengan tingkat kekuatan dari self-efficacy mereka mengenai kemampuannya sendiri. Misalnya seorang siswa mempunyai harapan yang lemah atau rendah, ketika siswa mengalami kegagalan terhadap tugas matematika sebelumnya, maka hal tersebut akan mempengaruhi self-efficacy siswa itu sendiri sehingga hal tersebut akan mempengaruhi motivasinya untuk belajar. Sebaliknya, siswa yang memiliki harapan yang tinggi, akan mendorongnya untuk tetap bertahan dan selalu berusaha.

\section{3) Tingkat generalisasi (generality)}

Dengan skor rata-rata 30. Pada dimensi ini self-efficacy dipandang sebagai keyakinan seseorang terhadap kemampuan dirinya untuk melakukan tindakan-tindakan yang diperlukan untuk menyelesaikan soal atau permasalahan yang melibatkan kemampuan siswa itu sendiri sehungga berhasil. Sehingga pada dimensi ini bagaimana respon mereka terhadap mata pelajaran matematika baik itu kesiapan belajar atau keaktifan mereka saat pembelajaran, hal ini mempengaruhi hasil belajar siswa dan keyakinan mereka. Siswa dengan self-efficacy yang tinggi memiliki kualitas strategi belajar yang lebih baik dari pada siswa yang memiliki self-efficacy rendah sehingga siswa yang memiliki self-efficacy yang positif terhadap matematika akan mempengaruhi siswa dalam pengambilan keputusan dan mempengaruhi tindakan yang akan dilakukannya. Makin tinggi self-efficacy seseorang, makin besar upaya, ketekunan yang dilakukan.

Melalui pengamatan terhadap proses pembelajaran yang dilakukan dengan pendekatan metematika realistik, siswa dapat mengumpulkan informasi yang diperlukan untuk membuat pertimbangan tentang kemampuan dirinya sendiri. Melalui pengalaman orang lain, ia dapat belajar dan dapat membuat keputusan bagaimana sebaiknya ia bertindak untuk situasi yang sedang ia hadapi, sedangkan pengelaman sendiri jika pengalaman itu berupa pengalaman tentang keberhasilan, maka ia dapat 
menggunakan pengalaman itu untuk situasi yang sedang ia hadapi. Bila pengalaman tentang kegagalan, maka ia dapat membuat keputusan untuk tidak melakukan hal yang sama. Pendekatan sosial atau verbal digunakan untuk meyakinkan seseorang bahwa ia memiliki kemampuan untuk melakukan sesuatu. Perlu diingat bahwa, pernyataan negatif tentang kompetensi siswa dalam pembelajaran matematika dapat berakibat buruk terhadap siswa yang sudah kehilangan keyakinan diri. Maka perlu hanya sebagai seorang guru kita memberikan dorongan serta penguatan kepada siswa hal itu akan berdampak positif bagi perkembangan selfefficacy siswa itu sendiri.

Berdasarkan hasil pengamatan aktivitas siswa dalam pembelajaran melalui pendekatan matematika realistik, yakni pengungkapan ide ini merupakan salah satu wujud pengalaman sendiri, proses penyajian hasil kerja kelompok, merupakan salah satu pengalaman orang lain, proses dalam diskusi kelompok merupakan salah satu wujud membentuk aspek sosial dan aspek psikologis. Gambar berikut bagaimana siswa beraktivitas dalam pembelajaran yang dapat memicu berkembangnya kemampuan self-efficacy siswa di dalam kelas.

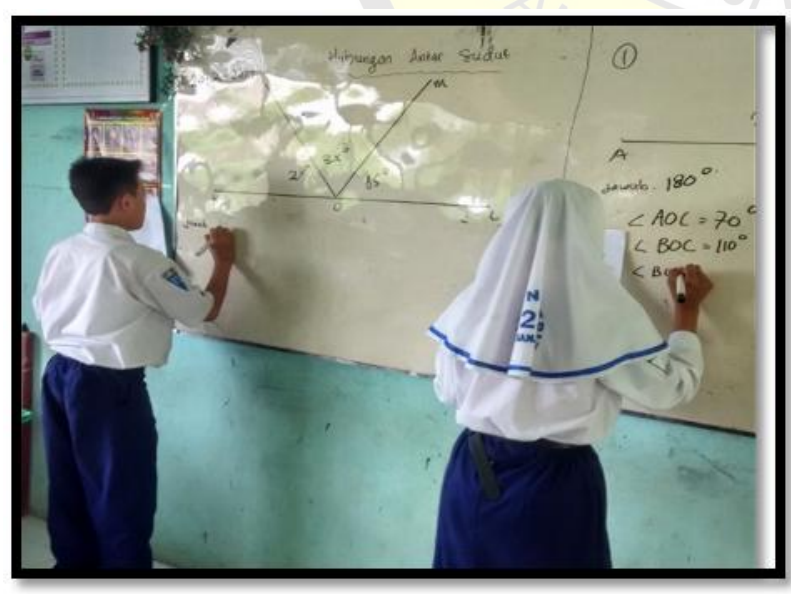

Gambar 4. Perwakilan siswa menuliskan hasil kerja kelompoknya
Pada gambar 4 sumber mastery experiences diperoleh siswa dari pengalamannya mengerjakan soal pada Lembar Kerja Siswa (LKS). Siswa yang menguasai cara penyelesaian rutin dan berhasil memecahkan masalah dalam LKS merasakan adanya perkembangan self-efficacy terhadap matematika pada dirinya. Setelah pembelajaran siswa yang gagal menyelesaikan LKS dan menganggap soal yang diberikan cukup sulit cenderung menghasilkan dua reaksi, yaitu pantang menyerah dan langsung putus asa. Saat diberikan tugas yang berkaitan dengan kehidupan mereka maka peluang siswa saling mencontek sedikit karena mereka fokus pada pengamatan atau pengalaman yang mereka alami. Semua siswa hampir mengerjakan soal-soal sendiri, minimal hanya bekerja sama dengan teman sekelompok saja karena tugas mereka yang sama ha ini akan mengembangkan kondisi pisikologis siswa dalam menilai kemampuan yang mereka miliki untuk mnyelesaikan tugas yang diberikan.

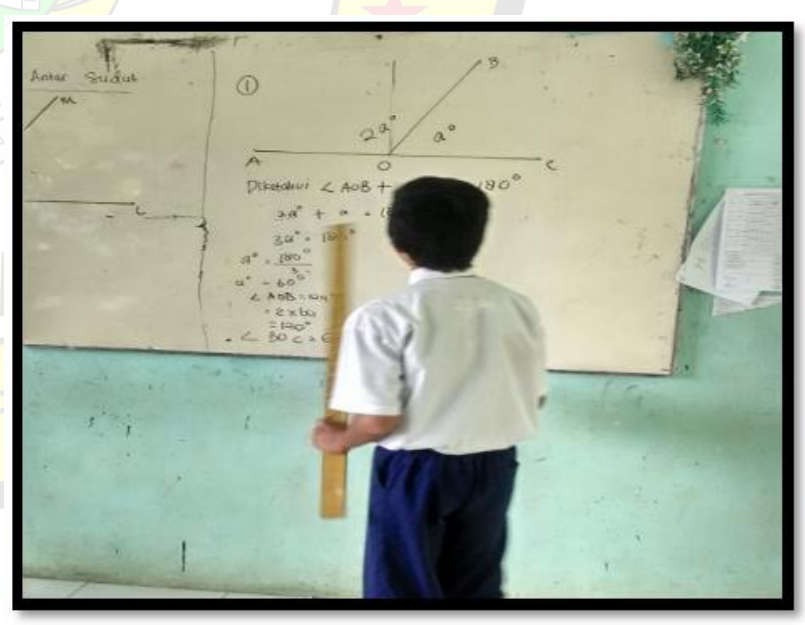

Gambar 5. perwakilan siswa menyampaikan hasil kerja kelompoknya

Pada gambar 5 di atas menujukan pengembangan vicarious experiences yang bersumber dari guru dan teman sebaya. Hal itu dapat dilihat pada gambar 5 terlihat seorang 
siswa mempresentasikan hasil kerja kelompoknya di depan kelas. Tampilan siswa ini merupakan wujud dari rasa percaya diri dalam menyampaikan hasil kerja kelompok di hadapan siswa lain dan dia memiliki kemampuan berkomunikasi secara efektif. Selain itu juga menghargai pendapat orang lain bila ada pertanyaan atau saran yang disampaikan oleh siswa dari kelompok lain. Dalam kegiatan pembelajaran, guru sebagai model bagi siswa dalam memberi saran perintah serta arahan dalam menyelasikan maslah yang diberikan. Sementara siswa secara berkelompok dalam belajar, sehingga siswa secara langsung melihat pengalaman siswa lainnya dalam menyelesaikan masalah yang diberikan, hal ini dapat menumbuhkan self-efficacy siswa terhadap matematika. Sehingga siswa yang memiliki rasa percaya diri, kerja keras, berani tampil dalam menguraikan gagasannya, kreatif dan kritis dalam berbagai pemecahan masalah yang ia hadapi, dan tidak mudah menyerah, maka hal itu akan menumbuhkan serta mngembangkan keyakinan mereka terhadap kemampuan yang mereka miliki.

Dari hasil pengamatan pula terlihat bahwa saat bekerja secara berkelompok sering terjadi debat pengetahuan dalam menyelesaikan masalah. Terjadi interaksi antar kelompok, saling mengajarkan dan bekerjasama satu sama lain. Siswa merasa mampu mengerjakan hampir semua tugas yang diberikan, dan dapat menyelesaikan masalah sendiri. Namun masih ada siswa yang mendapatkan temannya yang hanya menantikan hasil penyelesaian dari temannya, dalam arti tidak berpartisipasi aktif dalam kelompok.

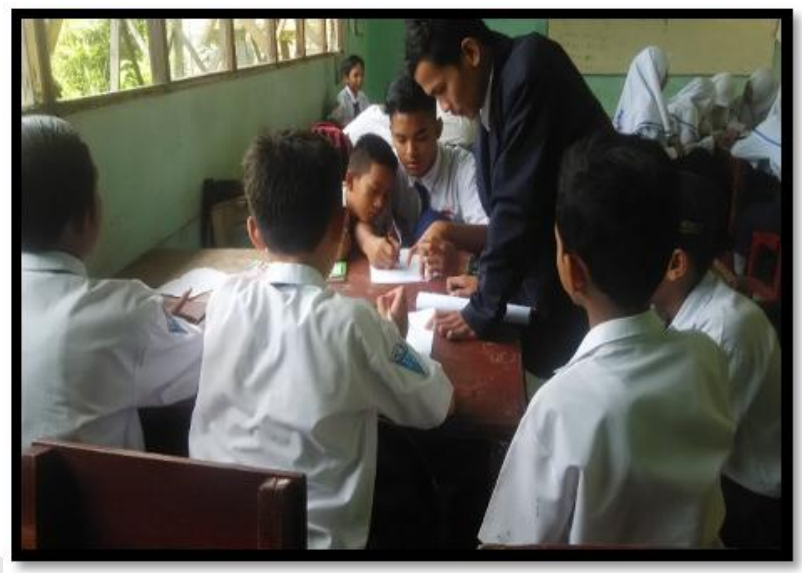

Gambar 6. Guru membimbing untuk mengerjakan masalah yang diberikan

Gambar 3 menunjukan sumber verbal persuasion berupa pertanyaan-pertanyaan yang membimbing siswa. Hal ini menjadikan petunjuk diri bagi siswa dalam menyelesaikan soal yang dihadapinya, sehingga semakin sering siswa melakukan atau menanyakan hal yang belum dipahaminya semakin siswa yakin untuk memahami setiap tahapan pemecahan masalahnya sehingga pisikologis siswa dalam menilai kempuannya dapat dikembangkan. Sehingga diharapkan pengungkapan ide-ide siswa itu dapat mnumbuhkan kemampuan komunikasi yang efektif, kerja keras, dan rasa percaya diri yang tinggi sehingga ide-ide yang baik itu bisa diwujudkan dalam bentuk pertanyaan, ataupun saran.

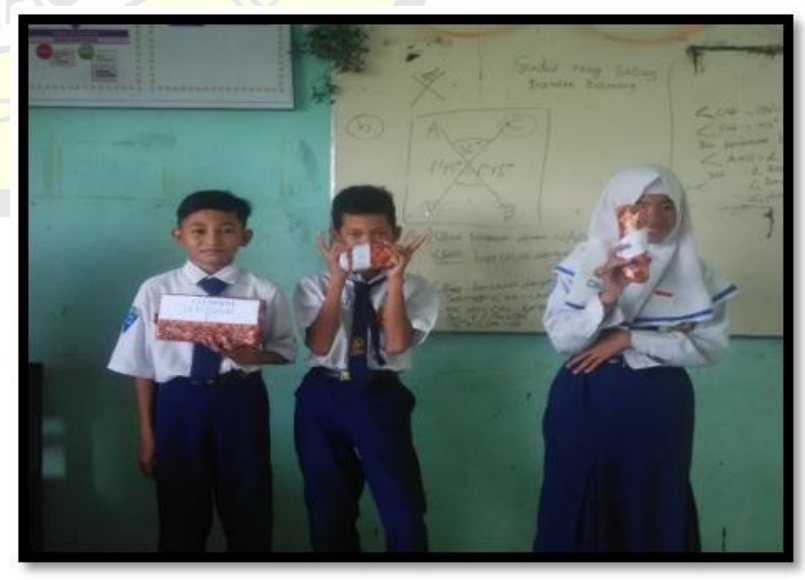

Gambar7. perwakilan dari kelompok terbaik menerima penghargaan 
Guru berupaya menciptakan kegiatan pembelajaran dengan melalui Pendekatan Matematika Realistik yang nyaman dan menarik untuk pengembangan sumber versuasi verbal Dalam penelitian yang dilakukan setiap pertemuan kelompok terbaik diberikan hadiah sehingga siswa menjadi tertarik dan berusaha agar menjadi kelompok terbaik. Dengan mencari benda sekitar atau sesuatu yang berhubungan dengan garis dan sudut di lingkungan sekolah sehingga mereka merasa nyaman dan menjadi lebih senang belajar matematika. Aktivitas yang terjadi pada kelas menunjukan bahwa saran Freedman (2012) agar siswa belajar santai dan nyaman benar-benar tercipta, sehingga kondisi tersebut dapat mengurangi kecemasan matematika siswa, begitu pula dengan interaksi antar siswa dalam pembelajaran. Kemudian beberapa siswa, tertantang dan bersemangat untuk mengerjakan soal dan tugas yang diberikan.

Teori yang memperkuat hasil penelitian ini antara lain teori Bandura (1986), yaitu bahwa seseorang yang memiliki self-efficacy yang tinggi akan sangat mudah dalam melakukan tugas-tugas yang sulit lebih baik sebagai sesuatu yang harus dikuasai bukan harus dihindari. Hal yang sama juga dikemukakan oleh Pajares \& Schunk (2001), yaitu bahwa efek positif secara konsisten akan penilaian self-efficacy tentang kinerja. Self efficacy mempengaruhi pilihan yang dibuat orang dan tindakan yang mereka inginkan. Selain itu, Bandura, (1998) mengemukakan bahwa self-efficacy dapat dibangkitkan dari diri siswa melalui empat sumber, yaitu (1) pengalaman kinerja; (2) pengalaman orang lain; (3) persuasi sosial; dan (4) keadaan pisikologi.

Hal ini sejalan dengan dengan moma (Hendriana 2009) yang mengataanbahwa untuk mengembangkan self efficacy paling tidak ada empat cara untuk menumbuhkan selfefficacy, pertama, yaitu dengan memahami betul apa yang harus dilakukan atau membiasakan diri untuk menyelesaikan tugas dengan baik (mastery learn to do the task well). Kedua, dengan mencari contoh dari orang lain dan mengamati cara kerjanya (modeling and observing others). Ketiga, dengan mencari dukungan atau support dari orang lain atau lingkungan. Keempat, dengan melakukan reinterpretasi terhadap stres, kerena bagaimana orang yang mempunyai kepercayaan diri selfefficacy pasti pernah berkali-kali mengalami kegagalan, tetapi selalu mengatasi rasa stress yang diderita akibat kegagalannya.

Data yang diperoleh dari jurnal mengenai pendapat siswa tentang pembelajaran yang dialami siswa melalui penerapan Pendekatan Matematika Realistik menunjukkan kesan baik. Siswa merasa senang dan nyaman dengan pembelajaran Pendekatan Matematika Realistik, pembagian kelompok yang berbeda. Dengan instruksi yang sama yang disesuaikan dengan kebutuhan siswa membuat mereka tidak dibeda-bedakan maupun direndahkan, siswa dapat mengerjakan sesuatu sesuai dengan kemampuannya.

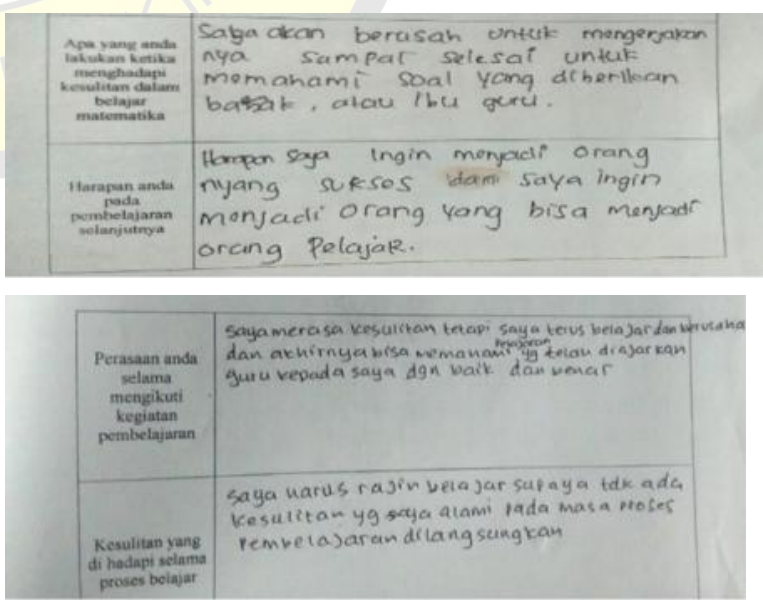

Gambar 8. contoh potongan jurnal siswa 
Dalam paparan siswa melalui jurnal terungkap bahwa, siswa tidak lagi merasa takut, ragu atau malu untuk mengajukan pendapat maupun bertanya. Hal ini mereka sampaikan dalam jurnal atau catatan yang mereka buat. Bahkan ada yang menuliskan bahwa pembelajaran yang mereka rasakan membuat mereka yang awalnya kurang suka dengan pelajaran matematika menjadi mulai suka dengan pelajaran matematika, yang awalnya menganggap matematika itu sulit, atau menakutkan menjadi lebih baik dan dapat menerima sedikit demi sedikit perasaan tersebut hilang.

Tidak sedikit siswa yang memiliki harapan dan semangat untuk lebih baik lagi dalam pelajaran matematika, karena seberapa besar atau kecil kemampuan mereka, melalui pembelajaran Pendekatan Matematika Realistik ini siswa yakin bisa lebih berkembang lagi. Berdasarkan jurnal siswa tentang pembelajaran Pendekatan Matematika Realistik dapat disimpulkan bahwa, siswa mempunyai respon yang positif terhadap pembelajaran Pendekatan Matematika Realistik dan pengembangan self efficacy mereka lebih baik.

\section{Simpulan}

\section{Simpulan dan Saran}

Berdasarkan hasil penelitian/dan pembahasan sebelumnya dapat disimpulkan self-efficacy siswa terhadap mata pelajaran matematika sebagai berikut:

1) self-efficacy siswa terhadap matematika sebelum pembelajaran melalui Pendekatan Matematika Realistik dengan persentase kategori rendah $40 \%$, kategori sedang $47 \%$, dan yang termasuk kategori tinggi 13\%. Sedangkan self-efficacy siswa terhadap matematika setelah penerapan pembelajaran melalui Pendekatan Matematika Realistik, diperoleh data tentang persentase self-efficacy siswa terhadap matematika menjadi $3 \%$ yang termasuk kategori rendah, $74 \%$ untuk siswa yang termasuk kategori sedang, dan $23 \%$ untuk kategori tinggi.

2) Berdasarkan hasil uji Wilcoxon menunjukan bahwa pengujian yang dilakukan uji satu pihak (uji pihak kanan) sehingga $\mathrm{P}_{\text {value }}$ yang digunakan adalah monte carlo sig (1-tailed) maka nilai $\mathrm{P}_{\text {value }}$ $=0.000$ sedangkan $\alpha=0.05$. karena $\mathrm{P}_{\mathrm{v}}<\alpha$ maka Ho ditolak dan $\mathrm{Ha}$ diterima, dengan taraf kepercayaan $95 \%$. Maka maka disimpulkan bahwa perkembangan self-efficacy siswa terhadap matematika sesudah diterapkan Pendekatan Matematika Realistik lebih baik dibandingkan sebelum diterapkan Pendekatan Matematika Realistik.

\section{Saran}

Saran dalam Penelitian ini diharapkan dapat guru, pihak sekolah maupun peneliti lainnya agar dapat melakukan penelitian dengan menggunakan variabel-variabel lain serta memperhatikan faktor-faktor yang mempengaruhi pembelajaran selain selfefficacy siswa, seperti self-estem dan selfregulated learning

\section{DAFTAR PUSTAKA}

Anwar, Astrid, I. D. (2009). Hubungan Antara Self-efficacy dengan Kecemasan Berbicacra di Depan Umum Pada Mahasiswa Fakultas Pisikologi Universitas Sumatera Utara. Skripsi. [Online]. 
http://repostory.usu.ic. Diunduh 24

Desember 2016.

Bandura, A. 1998. Social Learning Theory.

New York: General Learning Press.

[Online].Tersedia:

http://www.learningtheories.com/social-

learning-theory-bandura-html. Diunduh

29 Maret 2017.

Bandura, A. 1986. Self-efficacy. [Online]

Tersedia:

http://www.des.emory.edumfp/banEncy

:html. Diunduh 24 Maret 2016.

Eka dan Ridwan. 2015. Penelitian Pendidikan

Matematika. Bandung: PT Refika

Aditama.

Faturrohman, Muhammad. 2015. Model-

model Pembelajaran Inovatif.

Jogjakarta:Ar-Ruzz Media.

Ghufron M. Nur dan Risnawati Rini S. 2010.

Teori-Teori Psikologi.Jogjakarta:Ar-

Ruzz Media.

Hendriana dan Sumarno. 2014. Penilaian

Pembelajran Matematika. Cimahi: PT

Refika Aditama.

Hudojo, Herman. 1988. Mengajar Belajar

Matematika. Jakarta: P2LPTK.

Laili, Lutfia Nur (2015). Meningkatkan SelfEfficay Pelajaran Matematika

Menggunakan Layanan Penguasaan

Konten Dengan Tenik Modeling

Simbolik. Undergruadate thesis, UIN

Sunan Ampel Surabaya.

http://digilip.uin.ac.id/2474/ pdf diakses

24 November 2016.

Lestyanto, T. (2012). Hubungan Antara

Efikasi Diri Dengan Motivasi Belajar

Pada Siswa Kelas VIII SMP Negeri 3

Pati. Jurnal Pendidikan Nomor 2.

Muchid Abdul. 2009. Self-Eficacy Perspektif

Teori Kognitif Sosial dan Implikasinya

terhadap Pendidikan. Tadrîs. Volume 4.

Nomor 1. 2009.
Moma La. 2014. Self-Efficacy Matematik Pada Siswa SMP. Jurnal Pendidikan Matematika Volume 3, Nomor 2, Mei 2014.

Nursilawati. 2010. Hubungan slef-efficacy matematika dengan kecemasan menghadapi pelajaran matematika, UIN Syarif Hidayatullah. diakses http://repostory.uinjkt.ac.id pada 30 November 2016.

Siegle, Del, and D. Betsy McCoach. "Increasing Student Mathematics Self Efficacy Through Teacher Training." Journal of Advance Academics Vol.18 No.2, 2007: 27. 